\title{
Hydrated iron sulphate occurrences at Navarana fjord, Central North Greenland
}

\author{
ULLA HJORTH JAKOBSEN
}

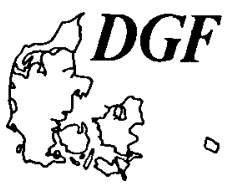

\begin{abstract}
Jakobsen, U. H.: Hydrated iron sulphate occurrences at Navarana fjord, Central North Greenland. Bull. geol. Soc. Denmark, Vol. 37, pp. 175-180. Copenhagen, April 10th, 1989. https://doi.org/10.37570/bgsd-1988-37-15

Several occurrences of readily soluble hydrated sulphate minerals were found at Navarana Fjord in the northeastern part of Freuchen Land, central North Greenland.

The sulphate minerals are copiapite, fibroferrite, gypsum, rozenite, melanterite and roemerite. In addition, limonite and pyrite are found. The mineralization occurs in faults and is found with the minerals in the above succession with a yellow crust of copiapite at the surface down to roemerite at a depth of $1.35 \mathrm{~m}$. The generation of these sulphate minerals are considered to be a result of oxidation and hydration of pyrite. The sulphates, otherwise unstable at surface conditions, are preserved because of the very cold and dry climate in the arctic region of North Greenland.
\end{abstract}

Jakobsen, U. H. Institute of General Geology, University of Copenhagen, Øster Voldgade 10, DK-1350 Copenhagen K, Denmark. July 15th, 1988.

\section{Introduction}

A preliminary study of sulphate occurrences found at Navarana Fjord in 1984 (Steenfelt and Jakobsen, 1986; Jakobsen, 1987) (Fig. 1) was performed during the Geological Survey of Greenland mapping programme in central North Greenland, 1984-85.
The occurrences were discovered because of the very pronounced colour and morphology of the yellow copiapite crust. The occurrences of these minerals are not restricted to the area at Navarana Fjord but are also reported from other localities in North Greenland, e.g. at the bottom of (1) J. P. Koch Fjord (Peel, pers. comm. 1988), (2) the south side of Frederick E. Hyde Fjord
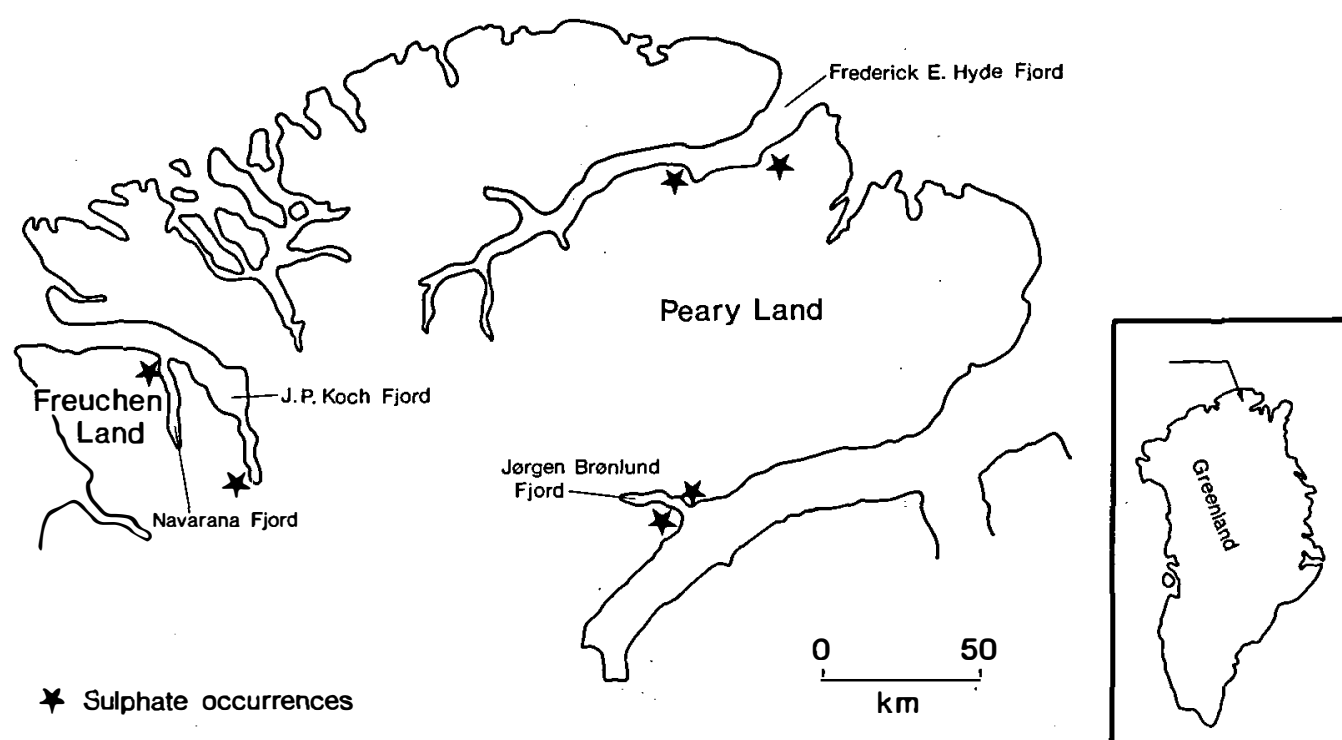

Fig. 1. Map showing the localities of the sulphate occurrences in central and eastern North Greenland. The described occurrences are located in the northeastern part of Freuchen Land. 


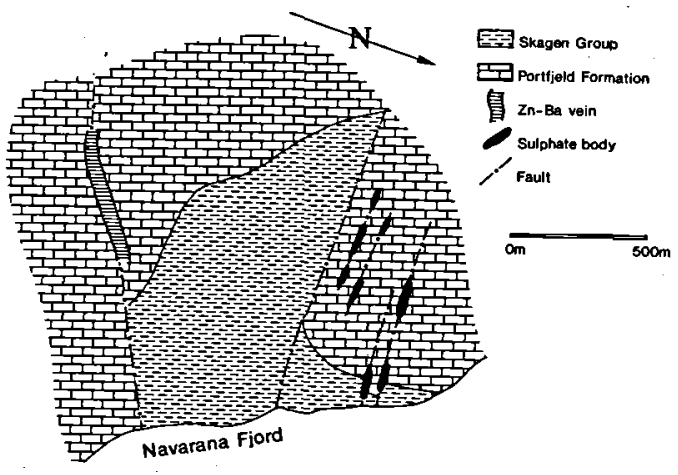

Fig. 2. Geological map of the Navarana Fjord area showing the localities of the sulphate occurrences. The locality of the $\mathrm{Zn}-\mathrm{Ba}$ vein type mineralization is also indicated.

(Dawes, pers. comm. 1988) and (3) on both sides of Jørgen Brønlund Fjord (Troelsen, 1949; Henriksen, pers. comm. 1986) (Fig. 1).

The occurrences at Jørgen Brønlund Fjord were described by Troelsen (1949) as a product of volcanic activity; this is rejected by the present study and an origin by secondary oxidation processes is put forward instead.

\section{Geological setting}

The host rock for the sulphate mineralization at Navarana Fjord consists of a sequence of unmetamorphosed sedimentary rocks of Lower Palaeozoic age (Hurst and Surlyk, 1982; Higgins and Soper, 1985; Ineson and Peel, in press).

The oldest rock unit within the area, the Skagen Group, consists of coarse to conglomeratic quartzitic sandstones which are followed by a dolomitic sequence, the Portfjeld Formation. Above these follow the shaly Buen Formation and a muddy carbonate to cherty shelf and slope sequence. The youngest unit in the area is a turbiditic sequence, the Merqujôq Formation.

The area is homoclinally folded with a NE-SW strike. Several small faults which are associated with the sulphate mineralization are found close to the Navarana Fjord.

Two other types of mineralization are observed in the area just south of the sulphate occurrences: (1) a carbonate-hosted $\mathrm{Zn}$ and Ba vein type mineralization in the Portfjeld Formation, and (2) a shale-hosted stratiform $\mathrm{Ba}-\mathrm{Zn}$ mineralization in the slope and shelf sequence (Jakobsen, 1987 and Jakobsen, in press).

\section{Analytical methods}

Mineral identification was carried out with a Guinier Hägg-camera, with quartz as internal standard. $\mathrm{Cu} \mathrm{K} \alpha_{1}$ radiation $(\lambda=1.54051 \AA)$ at the Institute of Mineralogy, University of Copenhagen. Chemical analyses for $\mathrm{Zn}, \mathrm{Ba}, \mathrm{Cu}, \mathrm{Pb}, \mathrm{Ni}$, $\mathrm{Cr}, \mathrm{Mo}, \mathrm{Co}, \mathrm{Fe}, \mathrm{Ca}, \mathrm{Mg}, \mathrm{Mn}$ and $\mathrm{Sr}$ were made on five samples from a vertical profile through one of the sulphate occurrences by atomic absorption spectrophotometry on a Perkin Elmer 460 , at the Institute of General Geology, University of Copenhagen. The samples have been decomposed both with a mixture of $6 \mathrm{ml} 25 \%$ $\mathrm{HCl}, 4 \mathrm{ml} 65 \% \mathrm{HNO}_{3}$ and $14 \mathrm{ml} 40 \%$ HF neutralized with $50 \mathrm{ml}$ satureted $\mathrm{H}_{3} \mathrm{BO}_{3}+2$ gram $\mathrm{H}_{3} \mathrm{BO}_{3}$ (powder) and with hot $\mathrm{HNO}_{3}(1: 1)$ in order to identify other mineralphases than sulphates in the samples e.g. sulphides. The data from the two methods gave identical results. The contents of $\mathrm{Ba}, \mathrm{Ni}, \mathrm{Cr}$, Mo and $\mathrm{Co}$ in the samples were all below the detection limits.

Table 1. Mineralogical data on iron sulphates.

\begin{tabular}{lllll}
\hline Mineral & Formula & Crystal system & Habit & colour \\
\hline Copiapite & $\left.\left(\mathrm{Fe}^{2+}, \mathrm{Mg}\right) \mathrm{Fe}^{3+}{ }_{4}\left[\mathrm{OH} \mid \mathrm{SO}_{4}\right)_{3}\right]_{2} \cdot 20 \mathrm{H}_{2} \mathrm{O}$ & triclinic & crusts & yellow \\
Fibroferrite & $\mathrm{Fe}^{3+}\left[\mathrm{OH} \mid \mathrm{SO}_{4}\right] \cdot 5 \mathrm{H}_{2} \mathrm{O}$ & hexagonal & finefibres & yellowish-green, silky \\
Rozenite & $\mathrm{Fe}^{2+} \mathrm{SO}_{4} \cdot 5 \mathrm{H}_{2} \mathrm{O}$ & monoclinic & prismatic & greenish-blue \\
Melanterite & $\mathrm{Fe}^{2+} \mathrm{SO}_{4} \cdot 7 \mathrm{H}_{2} \mathrm{O}$ & monoclinic & tabular & colorless \\
Roemerite & $\mathrm{Fe}^{2+} \mathrm{Fe}^{3+}{ }_{2}\left[\mathrm{SO}_{4}\right]_{4} \cdot 14 \mathrm{H}_{2} \mathrm{O}$ & triclinic & tabular & yellowbrown \\
\hline
\end{tabular}

Formulaes are in accordance with Roberts et al. (1974). 
Table 2. Geochemistry of a vertical profile through a sulphate body. Sample numbers are arranged from top to bottom of the profile.

\begin{tabular}{llrrrrrrrrrrr}
\hline $\begin{array}{l}\text { GGU } \\
\text { no. }\end{array}$ & $\begin{array}{l}\text { Main } \\
\text { mineral }\end{array}$ & $\begin{array}{c}\mathrm{Zn} \\
\mathrm{ppm}\end{array}$ & $\begin{array}{c}\mathrm{Cu} \\
\mathrm{ppm}\end{array}$ & $\begin{array}{c}\mathrm{Pb} \\
\mathrm{ppm}\end{array}$ & $\begin{array}{c}\mathrm{Fe} \\
\%\end{array}$ & $\begin{array}{c}\mathrm{Ca} \\
\%\end{array}$ & $\begin{array}{c}\mathrm{Mg} \\
\mathrm{ppm}\end{array}$ & $\begin{array}{c}\mathrm{Mn} \\
\mathrm{ppm}\end{array}$ & $\begin{array}{c}\mathrm{Sr} \\
\mathrm{ppm}\end{array}$ & $\begin{array}{c}\text { Sum } \% \\
\%\end{array}$ & $\begin{array}{c}\text { Calculated } \\
\mathrm{SO}_{4} \%\end{array}$ & $\mathrm{H}_{2} \mathrm{O} \%$ \\
\hline 313416 & Fibroferrite & 9 & 3 & 10 & 19 & 1.10 & 695 & 9 & $<3$ & 20.2 & 37 & 35 \\
313417 & Gypsum & 15 & 13 & 475 & 15 & 3.02 & 700 & 24 & 22 & 18.1 & 56 & 21 \\
313419 & Melanterite & 17 & 11 & 30 & 24 & 0.11 & 2300 & 34 & $<3$ & 24.4 & 35 & 45 \\
313419 & Melanterite & 16 & 11 & 25 & 22 & 0.26 & 1650 & 27 & $<3$ & 22.4 & - & - \\
313421 & Roemerite & 12 & 8 & 30 & 20 & $\mathbf{0 . 2 4}$ & 2500 & 26 & $<3$ & 20.5 & 48 & 31 \\
\hline
\end{tabular}

${ }^{*}$ Decomposed melanterite. $\mathrm{SO}_{4}$ and $\mathrm{H}_{2} \mathrm{O}$ are calculated values from the theoretical formulae.

\section{Results}

Field description of the sulphate mineralization

The sulphate mineralization in the Navarana Fjord area (Fig. 2) is found at eight localities in four small faults (vertical displacement c. $20 \mathrm{~m}$ ) cross cutting the rusty-red quartz conglomerate of the Skagen Group and the dolomitic Portfjeld Formation. The red colour of the conglomerate is due to weathering of pyrite in the conglomerate at these localities. The dolomite of the Portfjeld Formation is strongly tectonized against the faults and cemented by pyrite. Yellow sulphate, probably copiapite (Table 1) occurs in small cracks adjacent to the faults.

Each sulphate occurrence forms a 10-100 m long, domed body, $2 \mathrm{~m}$ high and $1-5 \mathrm{~m}$ wide, striking approximately $88^{\circ}$. On the surface a zonation occurs with copiapite $\left(\mathrm{Fe}^{2+}, \mathrm{Mg}\right)$ $\left.\left.\mathrm{Fe}^{3+}{ }_{4}\left[\mathrm{OH} \mid \mathrm{SO}_{4}\right)_{3}\right]_{2}: 20 \mathrm{H}_{2} \mathrm{O}\right)$ in the central and dominating part of the dome, followed by a thin outer rim of gypsum $\left(\mathrm{CaSO}_{4} \cdot 2 \mathrm{H}_{2} \mathrm{O}\right)$ and limonite $\left(2 \mathrm{Fe}_{2} \mathrm{O}_{3}: 3 \mathrm{H}_{2} \mathrm{O}\right)$.

A vertical profile $(1.35 \mathrm{~m})$ excavated in one of the sulphate domes revealed a pronounced and colourful zonation of different sulphates, limonite and pyrite. Mineralogical and geochemical data from this profile are given in Tables 1 and 2.

From top to bottom of the profile (Fig. 3), the uppermost two centimetres consists of copiapite followed by approximately $30 \mathrm{~cm}$ of alternating layers of yellowish green fibroferrite $\left(\mathrm{Fe}^{3+}\left[\mathrm{OH} \mid \mathrm{SO}_{4}\right] \cdot 5 \mathrm{H}_{2} \mathrm{O}\right)$, grey swallow-tail twinned gypsum crystals and red-brown limonite. Transition between the mineral zones is more or less diffuse. The succession continues downwards with a $90 \mathrm{~cm}$ bed consisting of a mixture of greenish blue melanterite $\left(\mathrm{Fe}^{2+} \mathrm{SO}_{4} \cdot 7 \mathrm{H}_{2} \mathrm{O}\right)$, often seen to radiate out from pyrite, and colourless roze- nite $\left(\mathrm{Fe}^{2}+\mathrm{SO}_{4} \cdot 4 \mathrm{H}_{2} \mathrm{O}\right)$. The pyrite content increases downwards and makes the rock both darker and heavier. At a depth of $125 \mathrm{~cm}$ the yellow brown (candy-coloured) roemerite $\left(\mathrm{Fe}^{2+} \mathrm{Fe}^{3+}{ }_{2}\left[\mathrm{SO}_{4}\right]_{4} \cdot 14 \mathrm{H}_{2} \mathrm{O}\right)$ appears, and has crystallized in small triclinic plates.

The minerals rozenite and roemerite have never been described from Greenland before, whereas the other minerals were described by Troelsen (1949). Troelsen (1949), on the other hand, mentioned an "undertermined brown iron compound" in the sulphate occurrences at Bronlund Fjord which conceivably could have been roemerite.

The profile was not excavated further down due to the permafrost layer, but massive pyrite was found in some of the faults and is considered to underlie the sulphates. The sulphate mineralization exposed at the surface seems to be in direct contact laterally with the Portfjeld Formation whereas the more massive pyrite at the

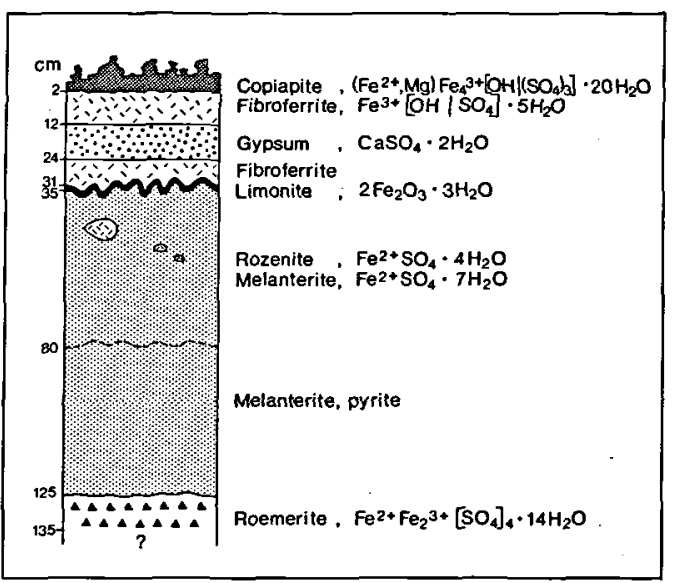

Fig. 3. Vertical profile through one of the sulphate occurrences in the Navarana Fjord area. The mineral species and formulae are shown to the right of the profile. 


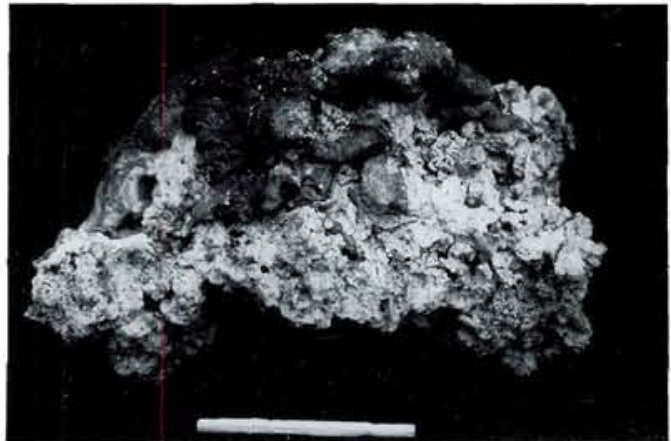

Fig. 4. Porous crust of yellow copiapite.

deeper levels in the faults is in contact with the Skagen Group.

\section{Mineralogy}

The minerals in the sulphate occurrences are described in order from top to bottom of the field profile. Mineralogical data on the iron sulphates are given in Table 1 .

Copiapite: Occurs as a yellow, finegrained aggregate of triclinic minerals which is always found as a porous crust at the top of the sulphate occurrences (Fig. 4), and in small cracks in the dolomitic Portfjeld Formation.

Fibroferrite: Yellowish green, silky, hexagonal fibrous mineral (1-5 mm in length) which occurs as a loose, unconsolidated layer in the uppermost part of the sulphate occurrences often alternating with gypsum and limonite. The mineral decomposes in water.

Gypsum: Grey, 1-2 $\mathrm{mm}$ in length, monoclinic mineral with swallow-tail twins occurring as a loose, unconsolidated layer together with fibroferrite and limonite.

Limonite: Red-brown mineral association which are found partly as a finegrained loose layer inside the profile and as a porous aggregate with boxwork texture at the surface surrounding the copiapite crust.

Rozenite: Colourless, very minute $(0.05-0.15 \mu$ in length) monoclinic crystals with a tabular habit found together with melanterite in the middle of the profile.
Melanterite: Greenish blue, translucent monoclinic mineral with a prismatic habit $(2 \mathrm{~mm}-2 \mathrm{~cm}$ in length). It occurs as a loose porous bed often together with rozenite and pyrite in the middle of the profile. Melanterite is often seen radiating out from pyrite (Fig. 5). The mineral becomes yellowish white on exposure.

Roemerite: Yellow-brown, translucent triclinic mineral which occurs in tabular crystals $(0.5-5$ $\mathrm{mm}$ in length). It is concentrated in a loose, unconsolidated layer at the bottom of the profile (1.4 $\mathrm{m}$ beneath the surface). Minor content of melanterite is seen together with roemerite. The mineral is soluble in water and the taste is metallic and astringent.

Pyrite: Primarily found with two morphologies: (1) as dissolution remnants together with melanterite in the middle of the profile, and (2) as more massive crystalline aggregates below the sulphate occurrences, in both the Skagen Group and the Portfjeld Formation.

\section{Geochemistry}

The concentation of $\mathrm{Zn}, \mathrm{Cu}, \mathrm{Pb}, \mathrm{Fe}, \mathrm{Ca}, \mathrm{Mg}, \mathrm{Mn}$ and $\mathrm{Sr}$ of the five samples taken through the sulphide profile are given together with the main sulphate phase in the samples in Table 2.

Due to the strong solution methods used, the results in Table 2 should represent not only the presence of sulphates but also show if any traces of sulphides is present.

Generally a high content of iron (15-19 wt \%) and a relatively high content of calcium (0.11$3.02 \mathrm{wt} \%$ ) are seen in all samples. Strontium is below detection limit except for the gypsum dom-

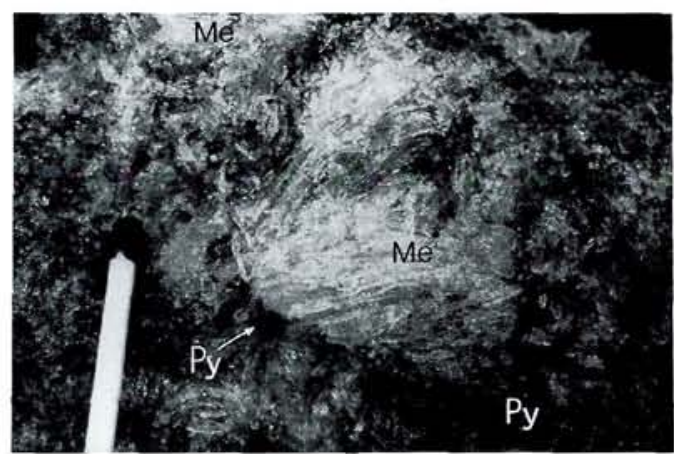

Fig. 5. Melaterite crystals radiating out from pyrite dissolution remnants. $\mathrm{Me}=$ melanterite, $\mathrm{Py}=$ pyrite. 
inated sample probably reflecting substitution of $\mathrm{Ca}^{2+}$ with $\mathrm{Sr}^{2+}$. Magnesium seem to follow the iron content reflecting substitution between those two elements. The concentration of $\mathrm{Zn}, \mathrm{Cu}, \mathrm{Pb}$, and $\mathrm{Mn}$ in the samples are all very low except for the gypsum dominated sample which have a content of $475 \mathrm{wt} \% \mathrm{~Pb}$.

The missing c. $80 \mathrm{wt} \%$ in all samples (Table 2) are in aggrement with the content of $\mathrm{SO}_{4}$ and $\mathrm{H}_{2} \mathrm{O}$ calculated from the respective formulaes for the sulphate minerals except for the gypsum dominated sample where the calcium content is to low if the sample should only contain gypsum as the sulphate phase. From the iron content of $15 \mathrm{wt} \%$, iron sulphates are considered to be present together with gypsum.

\section{Discussion and conclusion}

The observed succession of the relatively rare sulphate minerals associated with faults in the Navarana Fjord area reflects a process of mineralization and weathering:

At an early stage, probably contemporaneously with the Ellesmerian orogeny in Devonian - early Carboniferous time, faulting and brecciation occurred in the area. As a result, several minor faults occurred near the Navarana Fjord, four of which today host the sulphate occurrences and one of which today host the $\mathrm{Zn}$ and $\mathrm{Ba}$ mineralized vein (Jakobsen, 1989).

Probably in connection with the orogenic phase pyrite precipitated from a iron-rich fluid contemporaneously in the pore space in the sandy Skagen Group, in cracks in the dolomitic Portfjeld Formation and in the small faults cross cutting both formations. The fluid is from the geochemical results considered to be monometallic and to have carried only $\mathrm{Fe}^{2+}$ in solution. Even though the sulphate occurrences are close (c. 500 $\mathrm{m})$ to the $\mathrm{Zn}$ and Ba mineralized vein it does'nt seem probable that they should have any direct connection to each other.

At a later stage, postglacial until today, oxidation and hydration of pyrite in the Portfjeld Formation and in the uppermost part of the faults occurred by oxidated groundwater; a process described by Makovicky and Stresko (1966), who related the presence of such sulfhates to the influence of migrating groundwater with a very high oxidation potential on pre-existing pyrite occurrences. The groundwater is considered to be generated during the spring and summer periods when the active layer (which in the area around the sulphate occurrences is situated in the Portfjeld Formation) thaws and migration occurs towards the faults. In addition, $\mathrm{Ca}^{2+}$ and $\mathrm{Mg}^{2+}$ are leached out of the dolomitic Portfjeld Formation and transported by the groundwater to the faults where the oxidation processes occur.

The generation of the different sulphates occurs according to the generalized reactions:

$$
\begin{aligned}
& 2 \mathrm{FeS}_{2}+80_{2}+\mathrm{nH}_{2} \mathrm{O}->2 \mathrm{FeSO}_{4} \cdot \mathrm{nH}_{2} \mathrm{O}+ \\
& 2 \mathrm{H}_{2} \mathrm{SO}_{4} \\
& \mathrm{H}_{2} \mathrm{SO}_{4}+\mathrm{Ca}^{2+}+\mathrm{nH}_{2} \mathrm{O} \rightarrow>\mathrm{CaSO}_{4} \cdot 2 \mathrm{H}_{2} \mathrm{O}+2 \mathrm{H}^{+}
\end{aligned}
$$

The iron-sulphates are at suitable conditions later oxidized to ferric hydroxide and finally transformed to limonite (Levinson, 1980):

$$
\begin{aligned}
& 4 \mathrm{FeSO} \mathrm{S}_{4} \cdot \mathrm{nH}_{2} \mathrm{O}+10 \mathrm{H}_{2} \mathrm{O}->4 \mathrm{Fe}(\mathrm{OH})_{3}+ \\
& 4 \mathrm{H}_{2} \mathrm{SO}_{4} \cdot \mathrm{nH}_{2} \mathrm{O} \\
& 4 \mathrm{Fe}(\mathrm{OH})_{3} \rightarrow 4 \mathrm{FeO}(\mathrm{OH})+4 \mathrm{H}_{2} \mathrm{O}
\end{aligned}
$$

The oxidation of pyrite explains thus all the general features of zoning.

The content of iron and calcium in the analysed samples indicate that the samples mostly contain sulphate minerals and therefore no content of sulphides should be present. The high content of lead in the gypsum dominated layer is not readily explicable as lithogeochemical analyses from both the Skagen Group and the Portfjeld Formation around the faults have $\mathrm{Pb}$ contents below 16 ppm (Jakobsen, 1987). The low contents of Zn, $\mathrm{Cu}, \mathrm{Mg}, \mathrm{Mn}$ and $\mathrm{Sr}$ are in argreement with the lithogeochemistry around the suphate occurrences.

The duration and conditions of the weathering process today and in the future, and the initial amount of pyrite present will determine the size of the sulphate occurrences. In the Ege Khaya deposit in the U.S.S.R. a oxidation zone of c. 100 $\mathrm{m}$ is reported where more than $50 \%$ of the zone consists of readily soluble sulphates (Ivanov, 1966).

The presence and preservation of easily dissolvable sulphate minerals within the Arctic Circle of the U.S.S.R. has been described by Ivanov (1966) who explained their presence as the result of chemical weathering and their preservation as 
a result of the cold and dry arctic climate. The same arguments are considered valid for the Navarana Fjord area of North Greenland. The occurrences indicate that chemical weathering processes such as sulphide oxidation are active in an arctic climate like that in North Greenland.

Acknowledgements. I wish to thank A. Steenfelt and M. Ghisler for help in the field, E. Leonardsen for identifying the sulphate minerals and B. Damgard for the geochemical results. J. Konnerup-Madsen, H. Stendal, E. Makovicky, and K. Secher are greatly thanked for critically reviewing the manuscript. J. C. Bailey is thanked for improving the English of the manuscript. The paper is published with the permission of the Director of the Geological Survey of Greenland.

\section{Dansk sammendrag}

Flere forekomster af hydratiserede sulfat-mineraler er fundet ved Navarana Fjord i den nordøstligste del af Freuchen Land i det centrale Nordgrønland.

Sulfat-mineralerne udgøres af copiapit, fibroferrit, gibs, rozenit, melanterit og roemerit. Mineraliseringerne findes i forkastninger, hvor mineralerne findes $\mathrm{i}$ den givne rakkefølge og startende med en gul skorpe af copiapit ved overfladen ned til roemerit $i$ en dybde af $1.35 \mathrm{~m}$.

Dannelsen af disse sulfat-mineraler, der normalt er ustabile $i$ overfladenære miljøer, er et resultat af oxidation og hydratisering af pyrit. Sulfaternes bevarelse skyldes det meget kolde og tørre klima i det arktiske Nordgrønland.

\section{References}

Higgins, A.K. and Soper, N.J. 1985: Cambrian-Lower Silurian slope and basin stratigraphy between northern Nyeboe Land and western Amundsen Land, North Greenland. Rapp. Gronlands geol. Unders. 126, 79-86.

.Hurst, J.M. and Surlyk, F. 1982: Stratigraphy of the Silurian turbidite sequence of North Greenland. Bull. Grønlands geol. Unders. 145, $121 \mathrm{pp}$.

Ineson, J. and Peel, J.S. in press: Cambrian shelf stratigraphy of the Peary Land region, central North Greenland. Bull. Gronlands geol. Unders.

Ivanov, O.P. 1966: Basic factors in the development of sulfide deposit oxidation zones under permafrost conditions. $\mathrm{Ge}$ okhimiya, 1966, 1095-1105 (in Russian). Translation: Ge ochem. Intern. 1966, 875-884.

Jakobsen, U.H. 1987: En malmgeologisk og geokemisk undersøgelse af et $\mathrm{Zn}-\mathrm{Ba}$ mineraliseret omride i Freuchen Land, Centrale Nordgronland. M. Sc. thesis, Geologisk Centralinstitut, Københavns Universitet. 2 vol. $(86+82$ pp).

Jakobsen, U.H. 1989: Stream sediment and soil sample investigation of a zinc and barium mineralized area, Freuchen Land, Central North Greenland. J Geochem. Explor., vol. 31.

Levinson, A.A. 1980: Introduction to exploration Geochemistry. Appl. Pub. Co., Calgary. 72-86.

Makovicky, E. and Stresko, V. 1966: Slavikite from Medzev near Kosice, Czechoslovakia. Tschermaks Min. Petr. Mitteilungen, 12, 100-109.

Roberts, L.W., Rapp, G.R. and Weber, J. 1974: Encyclopedia of minerals. Van Nostrand Reinhold Company, New York.

Steenfelt, A. and Jakobsen, U.H. 1986: Malm i Nordgrønland. VARV 1986/1, 18-23.

Troelsen, J.C. 1949: Contributions to the geology of the area around Jørgen Brønlund Fjord, Peary Land, North Greenland. Medd. om Grønl. 149 (2), 29 pp. 